\title{
ANALISIS KEBUTUHAN PENGEMBANGAN BUKU AJAR GENETIKA MENDEL PADA MATAKULIAH GENETIKA DI UNIVERSITAS NEGERI MEDAN
}

\author{
Naimatussyifa Daulay ${ }^{1 *}$, Tumiur Gultom ${ }^{1}$, Martina Restuati ${ }^{1}$ \\ ${ }^{1}$ Universitas Islam Negeri Sumatera Utara \\ *syifalovato@gmail.com
}

\begin{abstract}
ABSTRAK
Ketersediaan buku ajar yang mengacu pada Permenristekdikti No. 44 Tahun 2015 bahwa wajib ditambah bentuk pembelajaran berupa penelitian, perancangan, atau pengembangan yaitu mengintegrasikan hasil penelitian dalam pembelajaran, serta didukung dengan Kurikulum Kerangka Kualifikasi Nasional Indonesia (KKNI) yaitu kegiatan mini riset adalah terbatas. Penelitian ini bertujuan untuk menganalisis kebutuhan pengembangan buku ajar pada topik Mendel matakuliah Genetika di Universitas Negeri Medan. Penelitian ini merupakan penelitian deskriptif eksploratif. Subjek penelitian adalah mahasiswa pendidikan biologi dan non kependidikan biologi yang telah atau sedang mengambil matakuliah Genetika. Sampel dipilih secara acak sebanyak 47 mahasiswa. Data dikumpulkan dengan menggunakan kuesioner dan angket mahasiswa. Teknik analisis data dilakukan secara deskriptif kuantitatif. Hasil penelitian menunjukkan bahwa 59\% referensi yang digunakan mahasiswa dalam perkuliahan Genetika selama ini hanya berupa satu buku pegangan sendiri dan peminjaman buku di perpustakaan memiliki stok terbatas. Hasil angket analisis kebutuhan pengembangan buku ajar menunjukkan bahwa 78\% kebutuhan pengembangan buku ajar Genetika berbasis riset perlu dilakukan. Berdasarkan data hasil penelitian tersebut dapat disimpulkan bahwa perlu dikembangkan buku ajar Genetika Mendel berbasis riset yang dapat memfasilitasi mahasiswa untuk belajar, baik dengan pendidik maupun secara mandiri melalui Kurikulum Kerangka Kualifikasi Nasional Indonesia (KKNI) yang berlaku yaitu mini riset.
\end{abstract}

Kata Kunci: Buku Ajar, Genetika Mendel, Drosophila melanogaster

\begin{abstract}
Availability of textbooks that refer to Permenristekdikti No. 44 of 2015 it is mandatory to add a form of learning in the form of research, design, or development, namely integrating research results in learning, and supported by the Indonesian National Qualifications Framework (KKNI) curriculum, which means that mini research activities are limited. This study aims was to find out textbooks that need to be developed on the topic of Mendel Genetic courses at Universitas Negeri Medan. This research is a descriptive exploratory study. Research subjects are students of biology education and non-biology education who have taken or are currently taking Genetic courses. Samples were randomly selected as many as 47 students. Data was collected using a questionnaire. Data analysis technique is by descriptive quantitative. The results showed that $59 \%$ of the references used by students in genetics learning were only in the form of one own handbook and the books borrowed from the library had limited stock. The results of questionnaire analysis of the need for textbook development showed that 78\% of the need for research based genetics textbook development needs to be done. Based on the research data, it can be concluded that a research based Mendel Genetic textbook needs to be developed that can facilitate students to learn, both with educators and independently through the Indonesian National Qualification Framework Curriculum (KKNI), namely mini research. This study is also part of the research-based development study of Mendel Genetics textbooks in the Biology Major Universitas Negeri Medan.
\end{abstract}

Keywords: Textbook,Mendel Genetic,Drosophila melanogaster 
Naimatussyifa Daulay, Analisis Kebutuhan Pengembangan Buku Ajar Genetika Mendel Pada Matakuliah Genetika di Universitas Negeri Medan

Jurnal Biolokus: Jurnal Penelitian Pendidikan Biologi Dan Biologi Vol.3 (2)

\section{PENDAHULUAN}

Buku ajar merupakan media pembelajaran cetak yang berisi suatu ilmu pengetahuan hasil analisis terhadap Kurikulum dalam bentuk tertulis. Penyusunan dari buku ajar ini yaitu menyediakan buku ajar yang sesuai dengan tuntutan Kurikulum dengan mempertimbangkan aspek kebutuhan mahasiswa antara lain sesuai dengan karakteristik dan lingkungan mahasiswa, membantu mahasiswa memperoleh alternatif buku ajar selain buku teks, dan memudahkan seorang pendidik dalam proses pembelajaran (Habibi, 2016). Berdasarkan hasil survey yang diberikan kepada 20 mahasiswa Jurusan Biologi Universitas Negeri Medan bahwa mereka hanya memiliki satu buku pegangan sendiri dalam belajar Genetika, sementara ketersediaan buku di Perpustakaan terbatas.

Berdasarkan informasi yang diperoleh dari Dosen Genetika tentang topik Genetika Mendel bahwa topik tersebut sulit dipahami juga abstrak oleh Mahasiswa S1.Genetika menjadi salah satu topik paling sulit dalam pendidikan sains (Tsui, 2010).Genetika sulit untuk dibelajarkan oleh peserta didik, salah satunya yaitu Hereditas, sehingga dibutuhkan suatu teknik yang baik dalam membelajarkannya (Jalmo, 2018). Selain itu bahan ajar khususnya di Jurusan Biologi Universitas Negeri Medan yang tersedia hanya berupa diktat, buku Genetika dan penuntun praktikum. Melalui persebaran angket analisis kebutuhan mahasiswa sebanyak 27 Mahasiswa bahwa 85\% menyatakan buku ajar yang digunakan mengkaji Genetika Mendel ada namun tidak begitu mendalam, selain itu materi hanya berupa materi konten. 67\% menyatakan sulit dalam memahami materi Genetika Mendel.Melalui wawancara yang dilakukan pada 10 mahasiswa secara acak bahwa mereka abstrak dalam memahami Genetika Mendel dan butuh suatu buku panduan yang jelas dalam mempelajarinya.

Berdasarkan kuesioner yang diberikan kepada para mahasiswa S1 Jurusan Biologi
Universitas Negeri Medan bahwa cakupan Bab yang membahas Genetika Mendel kurang mendukung juga sulit dipahami bagi mahasiswa.Keberadaan Kurikulum Kerangka Kualifikasi Nasional Indonesia (KKNI) yaitu kegiatan mini riset juga menjadi salah satu faktor perlunya buku ajar baru bagi para mahasiswa.

Tujuan dari penelitian ini adalah untuk menganalisis kebutuhan pengembangan buku ajar pada topik Mendel matakuliah Genetika Universitas Negeri Medan. Hasil penelitian ini diharapkan dapat memberikan informasi mengenai buku ajar yang perlu dikembangkan pada topik Mendel yang dapat meningkatkan pemahaman dan dapat dipelajari secara mandiri oleh mahasiswa.

\section{METODE}

Penelitian ini merupakan penelitian deskriptif eksploratif. Subjek penelitian adalah mahasiswa pendidikan biologi dan non kependidikan biologi yang telah atau sedang mengambil matakuliah Genetika. Sampel dipilih secara acak sebanyak 47 mahasiswa. Data dikumpulkan dengan menggunakan kuesioner dan angket mahasiswa berupa pilihan berganda. Lokasi penelitian di Jurusan Biologi FMIPA Universitas Negeri Medan pada Januari sampai dengan Februari 2019. Lembar kuesioner dapat dilihat pada Tabel 1.

Angket analisis kebutuhan pengembangan buku ajar untuk mahasiswa berisi pertanyaan-pertanyaan bentuk pilihan berganda dengan empat pilihan a,b,c, atau d.

Teknik analisis data dilakukan secara deskriptif kuantitatif yaitu mendeskripsikan atau menjelaskan peristiwa yang terjadi pada saat sekarang dalam bentuk angka-angka yang bermakna (Sudjana, 1997). Pengolahan data yaitu dengan mengkalkulasikan total jawaban benar setiap butir pertanyaan dibagi total jumlah mahasiswa dikali 100\%.

Angket analisis kebutuhan pengembangan buku ajar untuk mahasiswa dapat dilihat pada Tabel 2. 
Tabel 1. Pertanyaan pada lembar kuesioner

\begin{tabular}{cl}
\hline No & \multicolumn{1}{c}{ Pertanyaan } \\
\hline 1 & Buku apa sajakah yang Anda gunakan dalam pembelajaran Genetika Mendel di Jurusan Biologi? \\
\hline 2 & Berapakah jumlah buku yang Anda gunakan dalam pembelajaran Genetika Mendel di Jurusan Biologi? \\
\hline 3 & $\begin{array}{l}\text { Apakah buku yang Anda gunakan dalam pembelajaran Genetika Mendel di Jurusan Biologi termasuk membeli } \\
\text { atau meminjam? }\end{array}$ \\
\hline 4 & Apakah Anda pernah melihat ketersediaan buku Genetika Mendel di Perpustakaan FMIPA Unimed? \\
\hline 5 & Apakah Anda pernah melihat ketersediaan buku Genetika Mendel di DigitalLibrary Unimed? \\
\hline 6 & $\begin{array}{l}\text { Kemukakan pendapat Anda terkait buku ajar yang Anda miliki atau pinjami terkait dalam mempelajari } \\
\text { Genetika Mendel. }\end{array}$ \\
\hline
\end{tabular}

Tabel 2. Pertanyaan pada angket kebutuhan

\begin{tabular}{cl}
\hline No & \\
\hline 1 & Bagaimanakah pendapat Anda tentang mata kuliah Genetika? \\
\hline 2 & Apakah Anda menyukai mata kuliah Genetika? \\
\hline 3 & Apakah Anda menggunakan buku sebagai sumber belajar pada mata kuliah Genetika? \\
\hline 4 & Jika Ya, berapa banyak jumlah buku yang Anda gunakan sebagai bahan ajar Genetika? \\
\hline 5 & Bagaimanakah menurut anda buku ajar Genetika yang anda gunakan saat ini? \\
\hline 6 & Apakah anda pernah melakukan mini riset selama perkuliahan? \\
\hline 7 & Berapa kali anda melakukan mini riset tersebut? \\
\hline 8 & Apakah anda pernah melakukan mini riset terkait mata kuliah Genetika? \\
\hline 9 & Pada materi apa sajakah anda melakukan mini riset tentang Genetika? \\
\hline 10 & Apakah di dalam buku ajar Genetika yang anda gunakan sudah disertai mini riset? \\
\hline 12 & Menurut anda pentingkah buku ajar Genetika disertai mini riset? \\
\hline 13 & $\begin{array}{l}\text { Menurut anda apakah dengan adanya buku ajar yang disertai mini riset dapat membantu anda melakukan } \\
\text { mini riset? }\end{array}$ \\
\hline 14 & Apakah ada materi Genetika Mendel di dalam buku ajar yang anda gunakan? \\
\hline 15 & Menurut Anda, apakah materi Genetika Mendel sulit dipahami? \\
\hline 16 & Apakah anda mengetahui prosedur tentang riset terkait Genetika Mendel? \\
\hline 17 & Apakah anda mengetahui mekanisme Genetika Mendel \\
\hline 18 & Menurut Anda, apakah penting buku ajar tentang Genetika Mendel berbasis riset? \\
\hline 19 & $\begin{array}{l}\text { Setujukah anda jika dikembangkan buku ajar tentang Genetika Mendel berbasis riset untuk mendukung mata } \\
\text { kuliah Genetika? }\end{array}$ \\
\hline 20 & Apakah buku ajar yang anda gunakan mengkaji Genetika Mendel? \\
\hline 21 & $\begin{array}{l}\text { Menurut anda, apakah dengan tersedianya aplikasi/penerapan konsep Mendel dalam penelitian dapat } \\
\text { mempermudah anda memahami konsep tersebut? }\end{array}$ \\
\hline 22 & $\begin{array}{l}\text { Menurut anda, apakah dengan adanya buku ini dapat menambah ilmu pengetahuan anda tentang Genetika } \\
\text { Mendel? }\end{array}$ \\
\hline
\end{tabular}

\section{HASIL DAN PEMBAHASAN}

Hasil analisis kebutuhan mahasiswa pada pengembangan buku ajar Genetika Mendel berbasis riset di Jurusan Biologi Universitas Negeri Medan dapat dilihat pada Gambar 1.

Hasil analisis kebutuhan pengembangan buku ajar menunjukkan bahwa $85 \%$ menyatakan buku ajar yang digunakan mengkaji Genetika Mendel ada namun tidak begitu mendalam, materi hanya berupa materi konten. $67 \%$ menyatakan sulit dalam memahami materi Genetika Mendel. Melalui wawancara yang dilakukan pada 10 mahasiswa secara acak bahwa mereka abstrak dalam memahami Genetika Mendel dan butuh suatu buku panduan yang jelas dalam mempelajarinya. Sebanyak $74 \%$ menyatakan sangat penting bahan ajar tentang Genetika Mendel berbasis riset dan 78\% dari mereka juga menyatakan bahan ajar disertai mini riset akan sangat membantu bagi mereka. Hal tersebut juga didasari dengan hadirnya kurikulum Kerangka Kualifikasi Nasional Indonesia (KKNI) yaitu kegiatan mini riset pada perkuliahan di Jurusan Biologi Universitas Negeri Medan. Hal ini juga diperkuat dengan Permenristekdikti No. 44 Tahun 2015 bahwa wajib ditambah bentuk pembelajaran berupa penelitian, perancangan, atau pengembangan yaitu mengintegrasikan hasil penelitian dalam pembelajaran. 


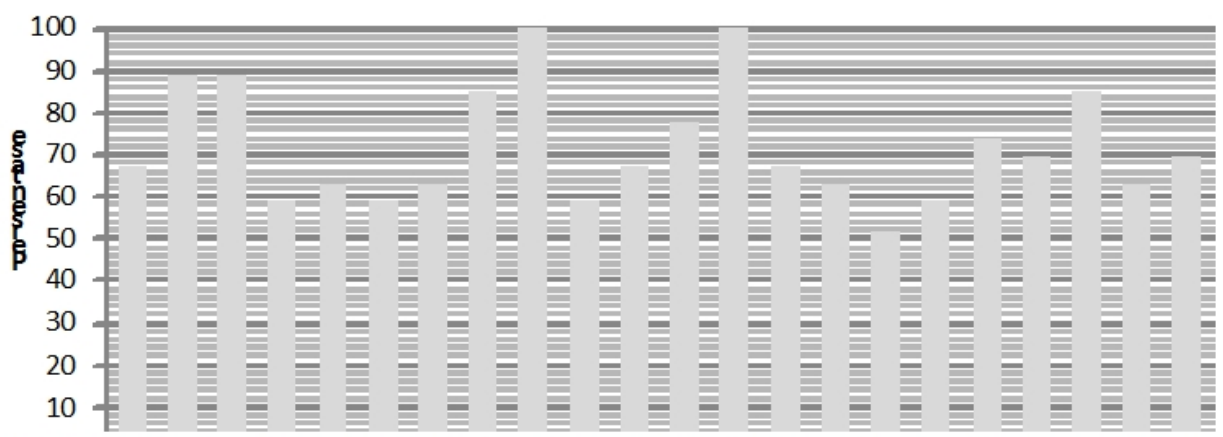

Ket: (A) Genetika san gat penting (B) Suka mata kuliah Genetika, (C) Sumber belajar Genetika, (D) Menggunakan satu buku untuk Genetika, (E) Buku Ajar Genetika belum lengkap, (F) Kadang-kadang M ini Riset, (G) Satu kali Mini Riset, (H) Kadang-kadang Mini Riset Pada Genetika, (I) Hany a pernah pengamatan siklus hidup pada Drosophila Sp, (J) Buku tidak disertai Mini Riset, (K) Sangat penting Buku Ajar Genetika, (L) Buku Ajar disertai Mini Riset akan san gat membantu, (M) Materi Genetika M endel ada dibuku, (N) Materi Genetika M endel sulit dipahami, (O) Penting pemahaman tentang Genetika Mendel, (P) Tidak mengetahui prosedur riset terkait Genetika Mendel, (Q) Tidak mengetahui mek anisme Genetika Mendel, (R) Sangat penting Buku Ajar Genetika Mendel berbasis riset, (S) Sangat setuju dikembangkan Buku Ajar Genetika M endel berbasis riset, |(T) Buku Ajar yang digunak an belu m mendalam men gkaji Genetika Mendel, (U) Penerapan konsep Mendel dalam penelitian dapat membantu, (V) Sangat setuju ada buku tentang Genetika Mendel

Gambar 1. Hasil Angket Kebutuhan Mahasiswa, 2019

Berdasarkan hasil kuesioner bahwa selama perkuliahan genetika, buku yang digunakan hanya berjumlah satu yaitu buku karangan dosen pengampu matakuliah Genetika. Adapun peminjaman buku dari perpustakaan adalah dua dengan stok yang sangat terbatas. Cakupan Bab yang membahas Genetika Mendel kurang mendukung juga sulit dipahami bagi mahasiswa. Buku-buku tersebut masih berupa materi kontekstual yang tidak disertai hasil riset. Proses pembelajaran yang diterapkan pada perkuliahan Genetika selama ini meliputi presentasi dan diskusi hasil kajian mahasiswa dari jurnal serta penjelasan tambahan dari dosen pengampu. Penugasan juga lebih ditekankan pada pembuatan makalah, walaupun ada penugasan mengenai mini riset namun tidak disertai panduan. Dosen pengampu matakuliah Genetika setuju untuk dikembangkan suatu buku ajar yang bersifat mandiri bagi para mahasiswa. Dengan adanya buku ajar berbasis riset ini diharapkan dapat menambah wawasan dan pemahaman konsep mahasiswa juga melatih psikomotorik dalam meneliti.

Analisis kebutuhan pengembangan buku ajar ini yaitu untuk mengetahui buku ajar yang sesuai dengan tuntutan Kurikulum dengan mempertimbangkan aspek kebutuhan mahasiswa antara lain sesuai dengan karakteristik dan lingkungan mahasiswa, membantu mahasiswa memperoleh alternatif buku ajar selain buku teks, dan memudahkan seorang pendidik dalam proses pembelajaran (Habibi, 2016). Terdapat materi yang seringkali mahasiswa sulit untuk memahaminya ataupun pendidik sulit untuk menjelaskannya. Kesulitan tersebut dapat juga terjadi karena materi tersebut abstrak dan rumit.Apabila materi pembelajaran yang bersifat abstrak, maka kelebihan buku ajar ini mampu untuk mahasiswa menggambarkan sesuatu yang abstrak tersebut misalnya dengan penggunaan gambar (foto) dan skema. Wulanzani (2016) bahwa bahan ajar yang dilengkapi dengan gambar dapat mendukung pembelajaran dan juga dapat merangsang peserta didik untuk menganalisis dan mengolah informasi.Rotter (2006) menyatakan bahwa gambar yang terdapat pada bahan ajar memberikan efek positif terhadap kemudahan peserta didik untuk membaca dan meningkatkan pemahaman. Demikian pula materi yang rumit, dapat dijelaskan dengan cara yang sederhana, melalui kegiatan riset 
Naimatussyifa Daulay, Analisis Kebutuhan Pengembangan Buku Ajar Genetika Mendel Pada Matakuliah Genetika di Universitas Negeri Medan

Jurnal Biolokus: Jurnal Penelitian Pendidikan Biologi Dan Biologi Vol.3 (2)

yang lebih aplikatif sehingga lebih mudah dipahami dan diingat.

Hasil riset yang diintegrasikan dalam bahan ajar efektif digunakan dalam pembelajaran karena lebih aplikatif dan memenuhi unsur kekinian (Parmin, 2012).Dengan adanya buku ajar tersebut diharapkan dapat meningkatkan rasa ingin tahu, mendorong mahasiswa untuk melakukan riset, kompetensi sebagai peneliti, juga dapat meningkatkan prestasi belajar mahasiswa Jurusan Biologi Universitas Negeri Medan.

Pembelajaran berbasis riset bertujuan untuk menciptakan proses pembelajaran yang mengarah pada aktifitas analisis, sintesis, dan evaluasi serta meningkatkan kemampuan mahasiswa dan dosen dalam hal asimilasi dan aplikasi pengetahuan (Widyawati, 2010).

Pembelajaran berbasis riset bersifat multifaset yang mengacu pada berbagai macam metode pembelajaran. Pembelajaran berbasis riset memberi peluang atau kesempatan kepada mahasiswa untuk mencari informasi, menyusun hipotesis, mengumpulkan data, menganalisis data, dan membuat kesimpulan atas data yang sudah tersusun, dalam aktifitas ini berlaku pembelajaran dengan pendekatan "learning by doing" (Widyawati, 2010).

Penelitian Srikoon dilakukan di beberapa universitas di Thailand tahun 2014 bahwa pembelajaran berbasis riset harus diterapkan di banyak jurusan untuk memperluas penelitian di semua institusi dan untuk menerapkan penelitian di bidang pendidikan serta kaitan antara penelitian dan pengajaran. Dari hasil penelitian menunjukkan bahwa pembelajaran berbasis riset dapat meningkatkan skor kelas eksperimen dalam beberapa variabel seperti penelitian dasar, keterampilan memecahkan masalah, kemampuan berpikir kritis, kemampuan bertanya, dan hasil belajar. Dengan demikian pembelajaran berbasis riset dapat memperbaiki dan mengembangkan kemampuan peserta didik dan membangun koneksi intelektual dan praktis yang kuat antara batasan penelitian dan pembelajaran.Pembelajaran berbasis riset ini diyakini mampu meningkatkan mutu pembelajaran mahasiswa khususnya di Jurusan Biologi Unimed, memperkaya wawasan, mendapat pengalaman lapangan, dan aktif pada kegiatan seminar penelitian.

\section{PENUTUP}

Berdasarkan tujuan penelitian, bahwa kebutuhan pengembangan buku ajar Genetika Mendel berbasis riset pada matakuliah Genetika di Jurusan Biologi Universitas Negeri Medan perlu dilaksanakan. Kurikulum KKNI digunakan di Jurusan Biologi yaitu kegiatan mini riset yang diharapkan dengan pengembangan buku ajar berbasis riset ini dapat memudahkan para mahasiswa dalam belajar Genetika Mendel.

\section{REFERENSI}

Habibi, Endang \& Mohammad. (2016). Pengembangan Buku Ajar Mata Kuliah Mikrobiologi Dasar. Jurnal Pendidikan: Teori, Penelitian, Pengembangan, 5(1), 2502- 471X.

Jalmo \& Tri. (2018). Biology Education Students' Mental Models on Genetic Concept. Journal of Baltic Science Education, 17(3), 2538-7138.

Kemenristekdikti. (2017) Pedoman Penyusunan Perangkat Pembelajaran Dan Bahan Ajar.

Pangastuti, A., Amin, M., \& Indriwati, E.S. (2016).Pengembangan Buku Ajar Biologi Sel Dengan Pendekatan Bioinformatika. Jurnal Pendidikan, 1(2), 116-121.

Parmin, Peniati, E. (2012). Pengembangan Modul Mata Kuliah Strategi Belajar Mengajar IPA Berbasis Hasil Penelitian Pembelajaran. Jurnal Pendidikan IPA Indonesia, 1(1), 8-15.

Permenristekdikti No. 44 Tahun 2015 Tentang Standar Nasional Pendidikan Tinggi.

Rotter, K. (2006). Creating instructional materials for all pupils: try cola.Intervention in School and Clinic, 41 (5), 273-282. 
Naimatussyifa Daulay, Analisis Kebutuhan Pengembangan Buku Ajar Genetika Mendel Pada Matakuliah Genetika di Universitas Negeri Medan

Jurnal Biolokus: Jurnal Penelitian Pendidikan Biologi Dan Biologi Vol.3 (2)

Srikoon, S., Bunterm, T., Samranjai, J. (2014). Research Synthesis of Research Based Learning For Education in Thailand. Procedia- Social and Behavior Sciences 116(1), 913-917.

Sudjana, N. (1997). CBSA Dalam Proses Belajar Mengajar. Jakarta: Rajawali Press.

Thiagarajan, S. (1974). Instructional Development For Training Teachers of Expectional Children. Minneapolis, Minnesota: University of Mminnesota.

Tsui, C. Y., and David, F. T. (2001).Teaching and learning reasoning in genetics with multiple external representations.Paper presented at the Australian Association of Research in Education. AARE 2001 Conference. Fremantle, Western Australia. 3-6 December 2001. Curtin University of Technology.
Tsui, C., \& Treagust, D. (2010). Evaluating secondary students' scientific reasoning in genetics using a two-tier diagnostic instrument.International Journal of Science Education, 32(8), 1073-1098.

Universitas Gadjah Mada. (2010). Pedoman umum pembelajaran berbasis riset; Yogyakarta.

Widyawati, Tri Diah D. (2010). Pedoman umum pembelajaran berbasis riset (pupbr). kerjasama antara pusat pengembangan pendidikan, kantor jaminan mutu, danlembaga penelitian dan pengabdian kepada masyarakat ugm universitas gadjah mada.

Wulanzani., Umie., Istamar. (2016). Hasil validasi buku teks mata kuliah bioteknologi berbasis bahan alam tanaman pacing (costus speciosus smith) sebagai anti fertilitas. Jurnal Pendidikan: Teori, Penelitian, Pengembangan, 9(1): 2502-471. 